This is an Accepted Manuscript of an article published by Taylor \& Francis Group in Jurisprudence on 04 Apr 2016, available online:

http://www.tandfonline.com/10.1080/20403313.2016.1148429.

Hope S (2016) Human Rights: Sometimes One Thought Too Many?, Jurisprudence, 7 (1), pp. 111-126. 


\title{
HUMAN RIGHTS: SOMETIMES ONE THOUGHT TOO MANY?
}

\author{
Simon Hope, Philosophy, University of Stirling*
}

Bio: Simon Hope is a Lecturer in Philosophy at the University of Stirling. His research primarily develops themes in Aristotelian and Kantian practical philosophy in response to modern debates about justice. Email: simonjames.hope@stir.ac.uk

\begin{abstract}
It is commonly claimed, in the global justice literature, that global injustices are best characterised in terms of the violation or unfulfillment of human rights. I suggest that global justice theorists are overconfident on this point. For decolonising peoples, contemporary global injustice is likely to be characterised in terms drawn from local histories of injustice and the constellations of thick ethical concepts they contain. To make the point I describe how the Māori of New Zealand, who do not reject human rights, typically make no reference to human rights in political argument. I argue that the Māori are reasonable to consider human rights talk to be "one thought too many", and the considerations that make this so typically apply in other post-colonial contexts of political activity.
\end{abstract}

Keywords: human rights, colonisation, global justice, Māori

\section{Seeing global justice in terms of human rights}

It is now increasingly commonplace, in the philosophical literature on global justice and human rights, to follow Thomas Pogge in holding that the systemic effects of the present global institutional order violate or leave unfulfilled the human rights of billions of people. ${ }^{1}$ I certainly do not wish to dispute Pogge's compelling argument that the current

1 Thomas Pogge, World Poverty and Human Rights (2nd ed. New York, Polity, 2008).

While Pogge's position is currently the most widely visible, Henry Shue's Basic Rights ( $2^{\text {nd }}$ ed. Princeton, Princeton University Press, 1980) has also been extremely influential 
global order is grossly unjust. What I wish to challenge is the assumption that this injustice is best characterised with reference to the unfulfilment or violation of human rights.

It is not hard to see why so many current global justice theorists might find an appeal to human rights attractive. Global justice theorists are concerned about the atrophy of cosmopolitan sentiment in modern liberal societies, ${ }^{2}$ to which the supposedly global reach of human rights talk provides a solution that is effective both domestically and internationally. Thus Pogge, seeking a standard of justice that is at once fine-grained and internationally politically effective, asserts that 'a conception of human rights is far more suitable than all the theoretical constructs currently discussed by academics'. ${ }^{3}$ Global justice theorists frequently echo this belief in the political effectiveness of human rights talk. It is claimed that 'for a growing number of people of all cultures in all regions' human rights provide 'attractive remedies' to injustice; 4 indeed, that human rights constitute a modern 'lingua franca', 5 or 'world culture', ${ }^{6}$ 'the common moral language' of 'peacetime global society' insofar as there is one.7

in putting human rights front and centre of the global justice debate. For examples of Pogge's (and Shue's) influence, see the various contributions to Thomas Pogge (ed.) Freedom From Poverty as a Human Right (New York, Oxford University Press, 2007) and to R. Cruft, S.M. Liao, and M. Renzo (ed.) The Philosophical Foundations of Human Rights (Oxford, Oxford University Press, 2015).

2 For example, Pogge, World Poverty and Human Rights, 24-26.

3 Pogge, World Poverty and Human Rights, 50; 56.

${ }^{4}$ Jack Donnelly, "The Relative Universality of Human Rights", Human Rights Quarterly $29: 1,2007,281-306$ at 288.

${ }^{5}$ John Tasioulas, "The Moral Reality of Human Rights", in Thomas Pogge (ed.) Freedom From Poverty as a Human Right (New York, Oxford University Press, 2007), 75-102, at 75.

${ }^{6}$ Martha Nussbaum, Frontiers of Justice (Cambridge MA, Harvard University Press, 2006), 304.

${ }^{7}$ Charles Beitz, The Idea of Human Rights (Oxford, Oxford University Press, 2009), 1. 
My aim in this paper is to raise the possibility that others elsewhere may see the injustices of the global institutional order in ways very different to the global justice theorists' view. This is not a disagreement over whether the global order is unjust, but a disagreement over the nature of the injustice. I shall suggest that in post-colonial contexts of political activity the unjust effects of the global institutional order may take on a hue coloured far more by local historical narratives of injustice than by human rights talk. To bring out the structure of such thinking, I shall focus on one particular case, that of the New Zealand Māori. The middle sections of my paper are given over to a lengthy account of how and why Māori prefer to avoid human rights talk when making claims of right. In the construction I will place on Māori thinking, this is because human rights talk appears, to Māori, as one thought too many. We can of course ask whether Māori are reasonable to hold to such thinking. I argue that an historically grounded answer to this question should be an affirmative one, and that the sorts of considerations that make reasonable the Māori avoidance of human rights talk are likely to be present in many other post-colonial contexts.

If my hypothesis is plausible, much theorising on questions of global justice may exhibit a kind of ignorance, recently and powerfully captured by Katrin Flikschuh: theorists transfer ideas from familiar domestic contexts to unfamiliar global ones without first asking how others elsewhere see matters. ${ }^{8}$ What is needed instead is a sufficiently historically and culturally textured account of how agents in different contexts of political activity see matters of justice. Questioning whether assertions of the political effectiveness of human rights talk are overconfident casts light on how much current theorising falls short in this regard.

I shall also gesture to a more abstract point. The belief in the considerable global political effectiveness of human rights talk intersects in a complex way with the justifications global justice theorists offer for human rights as a philosophical idea. For example, global justice theorists typically display considerable vigilance against

\footnotetext{
${ }^{8}$ Katrin Flikschuh, "The Idea of Philosophical Fieldwork: Global Justice, Moral Ignorance, Intellectual Attitudes", Journal of Political Philosophy 22:1, 2014, 1-26.
} 
inflationary conceptions of human rights..$^{9}$ This vigilance seems driven by two related concerns. There is a concern from the philosophical side, that our most plausible understanding of human rights should be fundamentally grounded in the most important or vital human needs and interests - the 'morality of the depths', in Henry Shue's oft-quoted phrase ${ }^{10}$ - and that too long and trivial a list of human rights becomes unmoored from this. But there is also a concern that too long and trivial a list of human rights will damagingly dilute the weighty political currency that human rights currently have. It is no accident that the standard philosophical justifications seek to preserve the political effectiveness of human rights talk.

Claims about the political effectiveness of, and the philosophical justification for, human rights also intersect at a deeper level. The political effectiveness of human rights talk is often taken to reflect, and be explained by, a considerable consensus on substantive moral conclusions. ${ }^{11}$ Justifications for the philosophical idea of human rights also typically make use of a substantive consensus. Differing justificatory strategies locate and characterise this consensus in different ways, depending on whether the grounds for the philosophical idea of human rights are given by (for example) the deliverances of ordinary moral reasoning; ${ }^{12}$ or of an overlapping consensus on values; ${ }^{13}$ or by an

${ }^{9}$ For example: Tasioulas, "The Moral Reality of Human Rights”, 75; James Griffin, On Human Rights (Oxford, Oxford University Press, 2008), 14-15; Beitz, The Idea of Human Rights, 45.

${ }^{10}$ Henry Shue, Basic Rights, 18.

${ }^{11}$ For example: Jonathan Wolff, "The Demands of the Human Right to Health", Proceedings of the Aristotelian Society Supp. vol. 86, 2012, 217-237, at 219; Donnelly, “The Relative Universality of Human Rights", 291-292.

${ }^{12}$ For example, Griffin, On Human Rights; Tasioulas, "The Moral Reality of Human Rights"; Wolff, "The Demands of the Human Right to Health"; see also Shue, Basic Rights, 179.

${ }^{13}$ For example, Nussbaum, Frontiers of Justice; Donnelly, "The Relative Universality of Human Rights". 
interpretive reconstruction of existing human rights practice. ${ }^{14}$ The latter two strategies must appeal to such a consensus: overlapping consensus arguments obviously rely on it, while interpretative strategies must begin with assumed agreement on 'paradigmatic instances' of - and thus some sense of the point and purpose of - the institutions or practices to be interpretatively reconstructed. ${ }^{15}$ Appeals to 'ordinary moral reasoning' need not invoke consensus if grounded in a sufficiently robust moral realism, but many such appeals do invoke consensus.

This is to say that vindications for the philosophical idea of human rights often proceed from the assertion that certain basic needs or values capture a common human consensus on what matters most. An extreme, though revealing, example is Jonathan Wolff's recent assertion that 'a great deal of political philosophy is now settled' by the practical consensus on human rights. ${ }^{16}$ Not everyone may want to go quite that far, but it is significant here that even critics of expansively cosmopolitan accounts of global justice allow that a minimal cosmopolitan position can be grounded in consensus on human rights. ${ }^{17}$

One consequence of this deep intersection between claims about the justification for human rights as a philosophical idea and claims about the political effectiveness of human rights talk is that it is very hard to see how, following the standard justificatory strategy, one could even register the ways in which claims about the global political effectiveness of human rights talk could be overstated. My main concern here is to raise the possibility that global justice theorists are too quick to assume that global injustices are best characterised through the language of human rights. But I shall also gesture to

\footnotetext{
14 For example, Beitz, The Idea of Human Rights; Raz, "Human Rights Without

Foundations"; and Andrea Sangiovanni, "Justice and the Priority of Politics to Morality", Journal of Political Philosophy 16:2, 2008, 137-164.

15 Sangiovanni, "Justice and the Priority of Politics to Morality", 148.

16 Wolff, "The Demands of the Human Right to Health", 220.

${ }^{17}$ For example, David Miller, "Cosmopolitanism: A Critique”, Critical Review of

International Social and Political Philosophy 5:3, 2005, 80-85.
} 
the further conclusion that, precisely because the standard justificatory strategy cannot register such overstatements, we should rethink that strategy.

\section{Human Rights Talk as a Mode of Legitimation}

To think about the political effectiveness of human rights talk is to think of human rights as what I shall call a mode of legitimation. As Quentin Skinner once rightly observed, 'any course of action will be inhibited to the degree that it cannot be legitimised. Any principle that helps to legitimise a course of action will therefore be among the enabling conditions of its occurrence.'18 Accordingly, I shall speak of diverse modes of legitimation: the particular constellations of normative considerations into which agents cast their chosen courses of action in order to secure the support of others.

And modes of legitimation certainly are diverse. Modes of legitimation may have moral content, and the human rights mode is an excellent case in point. Yet other effective modes may, for example, be pragmatic (appeals to efficiency or productivity) or grandly metaphysical (appeals to the direction, or indeed the end, of history). Nor must all modes aspire to be universal: some may be extremely parochial and no less effective for it, as in the enduring mode in American politics of casting one's action in line with Revolutionary values and aims. The effectiveness of any given mode of legitimation may also wax and wane over time: compare Marxist modes in Western European political contexts now as opposed to the 1950s. When a mode is effective, it will be subject to the pressures of rhetorical redescription from a variety of angles. ${ }^{19}$

There is a good reason why political modes of legitimation cover such an open-ended and unpredictable field. Michael Oakeshott makes the point well with his memorable nautical metaphor: 'in political activity, then, men sail a boundless and bottomless sea;

${ }^{18}$ Quentin Skinner, Visions of Politics vol I (Cambridge, Cambridge University Press, 2002), 156.

19 W.G. Runciman, “Cultural Selection, Axiological Rationality, and Paradiastole", Archives Europeenes de Sociologie 48, 2007, 173-189. 
there is neither harbour for shelter nor floor for anchorage, neither starting place nor appointed destination. The enterprise is to keep afloat on an even keel'.20 The constraints on what might stand as a mode of legitimation are contingent, determined by what is already there in existing traditions of political activity as they play out in current contexts. ${ }^{21}$ The existence of any specific mode of legitimation in any given context of political activity is therefore determined solely by the fact that its operation is recognised, by agents in the relevant context, as being effective.

With all this in mind, there is no doubt that human rights talk has come to represent a powerful mode of legitimation in many contexts of political activity. Yet while global justice theorists are keen to emphasise the effectiveness of human rights talk as a mode of legitimation, the way they do so is marked by a number of elisions. The human rights mode is invariably presented in isolation, both from the particular conditions in the 1970s within which the mode came to have the effectiveness it now enjoys, ${ }^{22}$ and from any other modes of legitimation that may be present in actual contexts of political activity. Accordingly, global justice theorists do not ask whether the conditions that make human rights an effective mode in some contexts apply in all current contexts, or whether other modes interact with the human rights mode in ways that limit its effectiveness. In post-colonial contexts I think it quite likely that other modes will have this limiting effect, and I want to emphasise the point by focussing on contemporary Māori political argument in New Zealand. To do this I will be speaking of Māori, who are of course the indigenous population of New Zealand, and also of Pākehā, the name by which New Zealanders of European extraction typically refer to themselves. I do not

\footnotetext{
${ }^{20}$ Michael Oakeshott, "Political Education", in Rationalism in Politics and Other Essays (London, Methuen, 1962), 127.

${ }^{21}$ It may be possible to say something in the abstract by adducing some basic "circumstances of politics" that no mode of legitimation could plausibly argue away. But such a list can tell us nothing about how such circumstances should be addressed - only that we must address them somehow. I say more on this in my "The Circumstances of Justice" Hume Studies 36:2, 2010, 125-148.
}

22 Samuel Moyn's The Last Utopia: Human Rights in History (Cambridge MA, Harvard University Press, 2010) is excellent on this point. 
choose to focus on the Māori context out of any desire to put Māori thinking on some kind of "exotic" pedestal, but simply because it is the context I am most familiar with.

\section{Human rights as one thought too many}

It is unwise to generalise too much about Māori political argument, and the following remarks are a tentative attempt by one Pākehā observer to understand only the Māori tendency to avoid appeals to the human rights mode of legitimation. This avoidance is not a matter of Māori rejecting the standard set of human rights: only a vanishingly small percentage of Māori endorse fundamentally illiberal outlooks. ${ }^{23}$ To philosophical proponents of human rights, this may seem to settle any controversy: if one accepts the standard view of human rights one can surely have no objection to seeing the colonisation of Māori, with all its inequality, violence, and prejudice, as a history of human rights violations. Here, it may be thought, is one more context in which injustices are best condemned through the human rights mode of legitimation. But that is not how Māori portray their own history and claims of right in political argument, and it is worth asking what they do and why they do it.

As to what Māori do, two examples will I hope suffice. Consider first the following remarks from a 1995 High Court affidavit by Ngāi Tahu scholar Hirini Moko Mead:

The act of whakawhānau [giving birth] produces a newborn child, a whenua [placenta] and eventually a pito [umbilical cord]. The whenua and the pito are buried or placed within the land of the whanau [extended family] and

\footnotetext{
${ }^{23}$ I emphasise this point to distance my argument from what has become known as the "human rights vs Asian values" debate. See further Hirini Moko Mead, Tikanga Mãori (Huia, Wellington, 2003), which is - although Mead does not stress the point explicitly a detailed meditation on the extent to which Māori culture is more liberal than it was.
} 
that establishes a spiritual link between the land and the child. Once born the child inherits a number of rights called a birthright. ${ }^{24}$

Mead is not simply describing a traditional Māori view. He is making a contemporary argument, appealing to the genealogical links that ground a bundle of fundamental and inalienable rights each and every Māori possesses by birthright. These are basic entitlements that all others, including governments and the law, must as a matter of justice respect.

Consider second, the claimants' arguments in the Waitangi Tribunal's Whanganui River Report. There one will find Māori claims of right to the river invoking the river's existence as an independent metaphysical being with its own mauri (lifeforce), invoking the whakapapa (genealogy) links that bind this entity to the local iwi*, and insisting that these genealogical ties mean that the mana ${ }^{\dagger}$ of the local iwi is complexly interpenetrated with the mana of the river itself and of its resident taniwha (sacred water creatures). ${ }^{25}$

${ }^{24}$ Te Rūnanga ō te Upoko ō te Iki Association \& ors v. The Treaty of Waitangi Fisheries Commission and others (1998), C.P. No. 122/95 (H.Ct. of New Zealand, Auckland Registery). Mead affidavit at 7-8.

${ }^{*}$ Whanau, hapu, and iwi all denote kin groups. Whanau = extended family; hapu = a number of whanau closely linked through genealogy; iwi = a number of hapu closely linked through genealogy. Each word also means birth (whanau), pregnant (hapu), and bone (iwi), again reinforcing the fundamental importance of genealogical ties. Traditionally hapu were the main social unit in Māori society; in the last century iwi have become so.

† Mana is a complex moral concept, possessed of individuals, groups, and both natural and supernatural entities. One's mana is a fundamental part of one's identity, describing one's worth, status, integrity, charisma, and influence. Mana also denotes authority, control, and jurisdiction; and is a fundamental aspect of the traditional Māori understanding of agency. There is a strongly metaphysical aspect to mana, expressed in the numerous ways the concept connects to that of tapu (roughly: the sacred or forbidden).

25 Waitangi Tribunal, Whanganui River Report, (Wai-167, Wellington, GP Publications, 1999), ch. 2. 
All of this amounts to a claim of authority over the river, of which Māori have been systematically dispossessed since the onset of the colonial period.

The thinking underlying these rights claims is well-captured by Moana Jackson:

In general terms, the rights of tāngata whenuał share the same concerns as those rights which the United Nations affirms... What makes them specific is the fact that... [the Māori set of rights] clearly exists and has a validity independent of international law. It is inherent in Māori law, in the concept of rangatiratanga*, and in the poetry of our whakataukī or proverbs. ${ }^{26}$

In making this point, Jackson is insisting that the justificatory grounds and validity of Māori claims of right to land, to resources, and to political authority and access to social institutions (rangatiratanga covers all these things ${ }^{27}$ ) rest, and should be seen as resting, solely on distinctively Māori considerations. And that is typically what Māori claims of right do rest on.

Māori arguments consistently assert a set of rights held uniquely by Māori, recognition of which must form the core of any just institutional arrangement for post-contact times.

* Tāngata whenua being a typical Māori expression referring to Māori as a group. Tāngata = "people"; whenua = "land", also "placenta", thereby neatly expressing the genealogical tie to the land that Māori have.

${ }^{*}$ Rangatiratanga $=$ (roughly) in modern usage, the rights and authority Māori should as a matter of justice have; the existence of a sphere of affairs in which Māori authority should be, if not supreme, very significant. Traditionally, rangatiratanga = the way of going on characteristic of a chief, including the rights and authority he or she possesses (rangatira $=$ chief).

${ }^{26}$ Jackson, "The Crown, the Treaty, and the Usurpation of Māori Rights", in Aotearoa New Zealand and Human Rights in the Asia Pacific Region: a Policy Conference (Wellington, Ministry of Foreign Affairs, 1989), 17-20 at 17. Compare Ani Mikaere, Colonising Myths - Mãori Realities: He Rukuruku Whakaaro (Huia, Wellington, 2011), 186.

27 See further my "The Roots and Reach of Rangatiratanga", Political Science 56:1, 2004, 23-54. 
Such rights are in a sense natural, as to be Māori is to possess this set of inalienable rights. But what is natural about such rights is explained by a distinctively Māori genealogical and animist understanding of nature. The justification for these rights is inseparably intermeshed with the significance of whakapapa: the genealogical links reaching back to creation that are utterly fundamental to Māori perceptions of personhood and culture, and whose importance shapes a whole range of Māori thick ethical concepts. In the words of Apirana Mahuika, 'whakapapa is the heart and core of all Māori institutions, from Creation to what is now iwi. Whakapapa is the determinant of all mana rights ... and one's place and status within society'. ${ }^{28}$

It is important to understand that Māori are not simply appealing to rights grounded in indigeneity or ethnicity. Māori typically consider whakapapa lines (and associated rights) to become shapeless and incoherent when generalised across Māoridom. Thus, Tūhoe elder John Rangihau declares:

My being Māori is absolutely dependent on my history as a Tūhoe person as against being a Māori person. Each tribe has its own history. And it's not a history that can be shared among others. How can I share with the history of Ngāti Porou, of Te Arawa, of Waikato? Because I am not of those people. I am a Tūhoe person and all I can share in is Tūhoe history .... I have a faint suspicion that Māoritanga is a term coined by the Pākehā to bring the tribes together. Because if you cannot divide and rule, then for tribal people all you can do is unite them and rule. Because then they will lose everything by losing their own tribal histories and traditions that give them their identity. ${ }^{29}$

What I hope is now clear is that whakapapa denotes a complex web of particular genealogical strands that each impart the rights that Māori claim. These rights are not rights claimable by any indigenous person in the manner of the 2007 UN Declaration.

\footnotetext{
${ }^{28}$ Apirana Mahuika, "Whakapapa is the Heart", in K.S. Coates and P.G. McHugh, Living Relationships (Wellington, Victoria University Press, 1998), 218-219; compare Mikaere, Colonising Myths - Mãori Realities, ch.11.

${ }^{29}$ John Rangihau, “Being Māori”, in M. King (ed.), Te Ao Hurihuri (Wellington, Hicks Smith, 1975), 190.
} 
When Māori ground claims of right in whakapapa they are deploying a mode of legitimation taking its terms solely from a uniquely Māori worldview. Of course, Māori also use and have used other modes of legitimation. Post-contact history reveals a number of at times ingenious Māori attempts at casting their claims of right into modes of legitimation that might gain better traction with European audiences: monarchical and biblical modes in the $19^{\text {th }}$ century; more liberal modes in more recent times. Yet there is an increasingly audible sense among Māori that they should not have to do this, that the assertion of Māori special rights should be accepted as legitimate on its own terms.30 And so this distinctively Māori mode now shapes the other modes of legitimation Māori deploy. When, for example, Māori appeal to the Treaty of Waitangi (a $19^{\text {th }}$ century document detailing a somewhat obscure division of authority between the Crown and Māori), they resist the common Pākehā assumption that the Treaty creates special contractual rights for Māori. Māori view the Treaty as simply protecting whakapapa rights that would exist even if the Treaty had never been signed, and in doing so bend the Treaty mode to the shape of the whakapapa mode. ${ }^{31}$ Mãori do the same on those occasions when they appeal to UN indigenous rights, detaching those rights from the universal grounding the UN language gives them. ${ }^{32}$ All of this is to say that the deployment of a distinctively Māori mode of legitimation is a persistent and significant feature of Māori political argument.

\footnotetext{
30 I discuss this further in "Justice and Legitimacy in Māori Claims: Reflections on F.M. Brookfield's Waitangi and Indigenous Rights", Australian Journal of Legal Philosophy 33:1, 2008, 179-192; see also Moana Jackson, "The Treaty and the Word: The Colonisation of Māori Philosophy", in G. Oddie and R. Perrett (ed.) Justice, Ethics, and New Zealand Society (Auckland, Oxford University Press, 1992); Mikaere, Colonising Myths - Māori Realities ch. 9.

${ }^{31}$ Hugh Kawharu, "Rangatiratanga and Sovereignty by 2040”, He Pūkenga Kōrero 1:2, 1996.
}

32 Mahuika, "Whakapapa is the Heart", 218-219, notes that while Māori 'employ the ethnic and iwi base when the circumstances demand it', ethnicity 'cannot usurp the mana and role of whakapapa'. For an excellent history of the unstable and temporary nature of Māori political agency as an ethnic group, see Lindsay Cox, Kotahitanga (Auckland, Oxford, 1993). 
It is worth registering, at this point, that Māori deploy this mode of legitimation in a context of political activity that is deeply multicultural. What makes the distinctively Māori mode of legitimation distinctively Māori is the constellation of thick ethical concepts it employs. These concepts are not part of the liberal social morality that Pākehā New Zealanders bear, and where Pākehā respect Māori practices or claims of right it is not typically because they accept, as Māori accept, concepts such as mana as reason-giving. Pākehā typically accept Māori claims of right, when and insofar as they do, because their own reason-giving concepts give them reason to. This makes for a complicated political muddle and fudge. It also makes for a Pākehā backlash of sorts, most typically through irate letters to media outlets and almost never through violence. Yet it has proved possible for Pākehā to take the distinctively Māori mode seriously enough, despite the generally poor Pākehā understanding of the whakapapa worldview, that the mode operates effectively: the backlash generated by Māori use of the whakapapa mode is never enough to silence its effectiveness.

This has been a rather lengthy account of what Māori do; I shall be briefer on the question of why they do it. The explanation for the Māori avoidance of the human rights mode is no doubt extremely complex, 33 and all I can do is stipulate here what I take to be one central part of that explanation. For Māori, the human rights mode of legitimation gets the nature of the injustice wrong. Māori claims are made in terms of the mana and rangatiratanga of the claimants, grounded in the claimants' whakapapa. If such claims were to be cast within the human rights mode of legitimation, these considerations would appear as culturally specific instances of whichever general human concerns ground the appropriate rights. To attempt to legitimise Māori demands for justice by casting them in the human rights mode of legitimation is thus unavoidably to portray the past and continuing injustices to be remedied as fundamentally and in the first instance violations of human rights rather than of Māori mana and rangatiratanga. Yet clearly, as far as Māori are concerned, it is mana and rangatiratanga that has been violated. For this reason casting the injustice in terms of the human rights mode of

\footnotetext{
${ }^{33}$ See further Jackson, "The Treaty and the Word: The Colonisation of Māori Philosophy", and Mikaere, Colonising Myths - Mãori Realities.
} 
legitimation would sound, I think to many Māori ears, a bit inappropriate - involving, one might say, one thought too many.

This way of putting things may sound as though there is no serious conflict between the whakapapa mode and the human rights mode: the justification for the claim that Māori suffered injustice is simply over-determined. Bernard Williams's readers will know better. The phrase "one thought too many" is deployed by Williams to mark considerations of reasoning that are inappropriate in light of the correct reasons for action. ${ }^{34}$ One might (in the case Williams discusses) save one's wife from drowning, rather than a drowning stranger, simply because she is your wife, or because one must always maximise the best consequences and in this case it turns out that saving one's wife achieves that. The first mode of reasoning is correct, and grasping this shows the second, overly impartial, mode of reasoning to be inappropriate. I think something similar is going on when Māori avoid human rights talk. A sophisticated conception of human rights will include respect for culture, so that respect for human rights necessarily involves respect for mana and rangatiratanga. But the problem remains: justice will still appear only indirectly concerned, in virtue of human rights, with Māori mana and rangatiratanga. There is still one thought too many. The only modes of legitimation that can actually capture what it is Māori demand are the distinctively Māori mode of legitimation and those that can be successfully bent to its shape. The human rights mode of legitimation is not one of those, and that I suspect is why Māori avoid it.

\section{Can human rights reasonably be one thought too many?}

So what should we say about this? The first thing to say is that in Williams's drowning wife scenario, it matters that the perspective from which we can see that there is 'one thought too many' in overly impartial forms of reasoning is the perspective of someone who understands the right reasons for action. This thought raises, in a rather stark way, the question of whether the Māori avoidance of human rights talk is reasonable. Human rights talk only appears as one thought too many from the standpoint of the whakapapa

\footnotetext{
${ }^{34}$ Bernard Williams, Moral Luck (Cambridge, Cambridge University Press, 1981), 18.
} 
worldview. If that worldview strikes you as an implausibly enchanted one, you may well conclude that the reasonable thing for Māori to do is shift to a different way of characterising injustice - say, in terms of human rights.

One could go further. The liberal social morality from which global justice theorists draw their conceptions of human rights articulates things that liberals sincerely believe about themselves and humanity. The terms of the Māori mode of legitimation are not part of that social morality; they are part of a genealogical animism that the liberal outlook typically rejects as false or side-lines as inappropriate to reasoned reflection on normative questions. It may therefore be very tempting to see the Māori use of the whakapapa mode as Māori making a conceptual last stand: ${ }^{35}$ a necessarily futile attempt at seeing things from a conceptual point of view for which the requisite concepts are lost; the futility of which goes unrecognised by those making the attempt because they refuse to wake up to the fact that their old form of life is gone. If one sees Māori political argument in this way, the question of the reasonableness of Māori invocations of whakapapa rights has a straightforward answer in the negative. It may seem as though the notion of toleration provides the best means for handling the question. One might say, appealing to the value of toleration, that a duty not to deny Māori usage of the whakapapa mode of legitimation, despite the unreasonableness of such usage, makes political sense.

However, there is also a question about the sorts of considerations we allow to bear on the question of whether the Māori avoidance of human rights talk is reasonable. It may seem attractive to take a very short line and reject as unreasonable the Māori insistence on deploying the whakapapa mode, by appeal to either the moral truth of human rights or to a stringently Rawlsian prohibition on richly metaphysical arguments. Yet these sorts of responses are too quick: they treat the question as a philosophical one (which it obviously is) without allowing that it is also a political one (which it also obviously is). The question of whether Māori are unreasonable to avoid human rights talk must have an historically-grounded answer, by which I mean we must take account of what the question presupposes about the agents, and their histories, we are asking it of. What it

35 I take the idea of a conceptual last stand from Jonathan Lear, Radical Hope (Cambridge MA, Harvard University Press, 2006), 26-33. 
presupposes is that the Māori need not see historical and continuing injustice in terms drawn from the whakapapa worldview. And in a sense this is true. The animist, genealogical worldview of whakapapa is not the only option Māori now have for understanding the world, and indeed they need to spend considerable energy in maintaining this option as a live one.

It is important to register the fact that it is only now a contingent matter, in a way that it was not then, that Māori perceive injustice in the way they do. ${ }^{36}$ Māori at the initial point of contact and colonisation could scarcely have seen the injustices that befell them in any terms other than those of the whakapapa worldview: that worldview provided, to Māori, the only available conceptual apparatus for making sense of their situation. ${ }^{37}$ It is of course a broader historical contingency that this was the case, as it was that the Māori outlook took the shape it did at that time, but those contingencies do not bear on the point at hand. What matters is that it remains the case that the Māori perception of injustice in the early contact era was and could only have been shaped by the whakapapa worldview alone.

\footnotetext{
${ }^{36}$ Here I owe a huge debt to J.G.A Pocock's "The Treaty Between Histories", in A. Sharp and P.G. McHugh (ed), Histories, Power, and Loss (Wellington, Bridget Williams, 2001).

${ }^{37}$ I realise this may be a controversial claim. Some, such as Gananath Obeyesekere, see human reason as fundamentally informed by practical concerns that are broadly the same everywhere; cultural contingencies do not cut deep. See Obeyesekere's heated exchange with Marshal Sahlins, in their respective The Apotheosis of Captain Cook:
} European Mythmaking in the South Pacific (Princeton, Princeton University Press, 1994) and How 'Natives' Think, About Captain Cook, For Example (Chicago, University of Chicago Press, 1995). My own view, which I cannot argue for adequately here, is that the forces which animate human reasoning do not amount to a shared substantively human form of life. For instance, the continual flux of cooperation and conflict between Māori and Europeans in the early post-contact period - captured in Anne Salmond, Two Worlds: First Meetings Between Mãori and Europeans 1642-1772 (Auckland, Viking, 1991) - can only adequately be explained in terms of a distance of understanding reaching far deeper than a simple lack of ability to communicate the deliverances of a substantively shared reasonable outlook to each other (or to the effects of unreasoned ideology). 
The position of contemporary Māori is different: they can, if they wish, draw on all the diverse and competing intellectual resources made available to them by the conditions of modernity. Yet putting things just like that obscures from view the ways in which the position of contemporary Māori is a deeply uncomfortable one. What makes the Māori experience of modernity uncomfortable is the way in which Māori have been forced, by the legacy of colonization, into a necessarily bicultural form of life. ${ }^{38}$ There is no feasible way for Māori to return to the pre-contact form of life, and any attempt Māori now make to define and defend a distinctively Māori form of life must involve grappling with the extent to which the contents of that form of life constitute a bricolage of diverse origins. Such attempts by Māori should not be confused with any nostalgic longing for an unrecoverable past. As Bernard Williams once wrote of how we stand in relation to the thought of our own philosophical ancestors, 'it is not a question of reviving anything. What is dead is dead, and in many important respects we would not want to revive it even if we knew what that could mean.'39 Māori are all too aware of this point, and the acknowledgement that the pre-contact form of life is unrecoverable is what drives Māori to fight so hard to preserve a distinctively Māori form of life now. In this, the Māori experience of modernity no doubt mirrors the experience of decolonising peoples generally.

For Maori, therefore, the fact that it wasn't then, but it is now, a contingent matter that Māori characterise injustice in terms of whakapapa rights itself now has political resonance. Just as the current abiding Māori sense of injustice involves an historical narrative linking together the injustices suffered in the post-contact period, so current Māori claims of right are seen by Māori as continuing a tradition of political activity aiming to resist and undo the injustices of colonisation; a tradition reaching back to the onset of colonial injustice. The fact that the worldview of whakapapa is not the only option Māori now have for characterising injustice itself cements the distinctively Māori

\footnotetext{
${ }^{38}$ Here I am indebted to Andrew Sharp's "Why Be Bicultural?”, in A. Wilson and M. Yeatman (ed.) Justice and Identity, (Bridget Williams Books, Wellington, 1995). See especially 131, n6.

${ }^{39}$ Bernard Williams, Shame and Necessity (Berkeley, University of California Press, 1993), 7.
} 
mode of legitimation at the core of this tradition of political activity, because the current contingency of the whakapapa worldview is part of the Māori narrative of injustice and loss. This should be totally unsurprising, given how that contingency came about. Māori political activity is historically informed in such a way that it is no simple matter for Māori to abandon the distinctively Māori mode of legitimation in favour of some other mode that cannot accommodate the contents of the Māori mode. For Māori to do so would, for example, be to concede that previous generations of Māori in the struggle against colonisation were in the grip of an error about the nature of the injustice suffered. I find it extraordinarily hard to conceive how, in any argument that seeks fidelity with the ongoing Māori tradition of attempting to erase the injustices of colonisation, the distinctively Māori mode of legitimation could be abandoned.

What I hope is now clear is that, while it is the constellation of thick ethical concepts at the centre of the Māori mode of legitimation that makes it distinctively Māori, it is the political resonance of these concepts that keeps the mode to the fore in Māori political activity. Māori have a continual tradition of characterising the injustices of colonisation in these terms, which is itself sustained by the way in which the contingency of the whakapapa worldview is a part of the narrative of colonial injustice. These political resonances effectively foist onto Māori political activity a constellation of ethical concepts that bear the historical deposit of the traditional Māori form of life, but also bear the historical deposit of Māori attempts at making sense of and inhabiting postcolonial circumstances. The fact that the whakapapa mode of legitimation takes its terms from a constellation of concepts that now bear a far more complicated historical deposit than they did 300 years ago illuminates the incredibly complex question facing Māori of what they take the Mãori worldview to be. While the current contingency of the whakapapa worldview is part of the Māori narrative of injustice, not all that was once in it but now lost is mourned. The whakapapa mode of legitimation is therefore at once outward-facing, used to legitimate claims of right in political engagement with Pākehā, and inward-facing - by which I mean it has an essential presence in debates among Māori about the shape and content of the whakapapa worldview.

I am now able to give an answer to the question of whether the Māori avoidance of human rights talk is reasonable. There is a real sense in which the whakapapa worldview remains a live option for Māori - it is not simply a conceptual last stand - and 
the sense in which it is a live option is imbued with deep political significance for Māori. That political significance must make any liberal response cast in terms of tolerating the Māori use of the distinctively Māori mode of legitimation appear to Māori as highhanded condescension. If this sounds right, then we will have to allow for the possibility that, while histories of colonisation are invariably histories of human rights violations, that is not necessarily all they are to those whose identities have been shaped by the experience. It may seem, to such people as it does to Māori, that human rights violations are not the most important aspects of their histories of injustice, and under certain conditions such people may reasonably resent attempts at casting their history as a history of human rights violations.

It is important that resentment is reasonable only under some conditions. The abolition of institutionalised racism in the American South, insofar as it has actually been abolished, is no doubt deeply resented by those racists who wish to, but can no longer, feasibly recover what they think of as a proper way of life (for instance, they seem very upset by the existence of interracial marriage). We would not want to say their resentment was reasonable. How we draw the line here should turn, in part, on whether we consider the resentment to be bound up in what is justifiably a history shaped by injustice. And that will involve doing some practical philosophy, giving a robust justification for the criteria of justice we're using when we draw that line.

For global justice theorists, the Southern racists' resentment will be straightforwardly unreasonable, because the racists' racism is thoroughly antithetical to the concerns grounding human rights. Things are different in the case of the colonised people asserting special natural rights, because the historical record of colonisation will itself typically create the conditions for reasonable resentment. Anyone whose reflection on questions of injustice is informed by the standard account of human rights should have no difficulty seeing histories of colonisation as cases where serious moral wrong has been done: that much is accessible, even if claims of special natural rights may sound more worrying. In the Māori case, the liberal history of New Zealand is also a history in which Māori suffer severe injustice, and this has proved sufficient to encourage the awkward navigation of the other side's constellation of thick concepts, and enables Pākehā to accept the Māori use of the whakapapa mode of legitimation. 
I am not suggesting that this thin convergence of histories is, of itself, sufficient to vindicate the reasonableness of the Māori avoidance of human rights talk. It cannot be, because a convergence in thin concepts - both sides agree "wrong" was done - cannot dissolve the fact that the thick concepts Māori use to characterise the nature of the wrong are not part of the liberal social morality. What vindicates the reasonableness of the Māori avoidance of human rights talk is that any plausible reflection on questions of injustice or wrongdoing will also have to acknowledge the historical deposit embedded in the moral concepts we use to characterise the wrongs of colonisation. Such reflection must also acknowledge how, within ongoing political traditions of resistance to colonisation, that deposit is perceived to relate to the historical record. The current contingency of the worldview of whakapapa, and the political resonances of that contingency, is one such case in point. Kofi Quashigah's contribution to this symposium highlights another: the political resonance in post-colonial constitutional jurisprudence in sub-Saharan Africa of anything resembling the "repugnancy test" of the colonial era. 40 It makes neither good political nor good philosophical sense to think that it is a simple or justifiable matter to recast the colonised's claims of right into modern liberal concepts and categories. And this conclusion can be reached without taking any view on whether genealogical animism, or any other outlook, accurately reflects the absolute conception of reality.

\section{A less uniform perspective on global injustice}

The reader, at this juncture, may be wondering just how far one can generalise the point I am seeking to make. All the world is of course not New Zealand. And that fact may seem to severely undermine my starting hypothesis that there may be relevant connections between the Māori context and other post-colonial contexts; especially those contexts which are the primary concern of global justice theorists. Although Māori are severely disproportionately represented at the wrong end of every social welfare statistic in New Zealand, they are in global terms well-off members of a stable, transparent democratic society. It may seem that the Māori argument in terms of whakapapa rights is a luxury that is unaffordable in many post-colonial contexts, and

\footnotetext{
${ }^{40}$ Quashigah, "Justice in the Traditional African Society Within the Modern Constitutional Set-Up", Jurisprudence, this volume.
} 
that where this luxury is unaffordable, the human rights mode of legitimation may seem to hold out by far the best possibility for securing action to condemn and rectify injustice.

This is an important point, but it does not show as much as the global justice theorist might think it does. Recall that Māori have deployed various modes of legitimation they hoped might be conducive to non-Māori ears; all the time holding that these modes did not adequately capture the nature of the injustice to be rectified and were, in the construction I am placing on Māori thinking, one thought too many. One would still be able to - and should - ask, of other post-colonial contexts where the systemic injustices of the global institutional order bite deepest, whether those in local forms of life grappling with the legacy of colonisation view the human rights mode of legitimation as an equally non-ideal option. And the flipside of that question is to ask to what extent the human rights mode appears, from the Western perspective, as a lingua franca simply because the West is not prepared to listen to anything other than the human rights mode.

It strikes me that the considerations that lead Mãori to avoid the human rights mode of legitimation may be widely generalisable across post-colonial contexts, in virtue of what I earlier called the at once inward and outward facing nature of the distinctively Māori mode. The political resonances of the distinctively Māori mode make it central to Māori political activity and claims of right against non-Māori and to the task of determining the current shape of the whakapapa worldview. Indeed, these two sets of questions interpenetrate to such a degree that I do not think one could sensibly see two completely distinct intellectual enterprises (claiming justice; sorting out the contents of a culture) here. So here is my suggestion: wherever the current contingency of an indigenous or traditional worldview is part of the local narrative of injustice, it is quite likely that significant political resonance will attach to a mode of legitimation that draws its terms from that worldview. There will (almost?) invariably be a need for political argument in post-colonial contexts to make use of modes of legitimation that, like the Māori mode, take their shape from the traditional worldview. 
That need will arise, at least in part, from the task of vindicating the present and ongoing shape the traditional worldview is held to take. It is not clear to me how that task could possibly be sensibly separated from political activity, and one excellent illustration of this is Quashigah's nuanced discussion, in this symposium, of how modern African constitutionalism navigates the confrontations between traditional social morality and a social morality that is at once African and shaped by an 'imported external view of life'. 41 It may of course turn out that in many post-colonial contexts what can be vindicated as the local equivalent to the whakapapa worldview may be more conducive to human rights talk - albeit perhaps a reconceptualisation of human rights talk ${ }^{42}$ - than the whakapapa worldview is. But this cannot be assumed as a matter of faith, and it is at least worth pausing to ask how well the human rights mode of legitimation fits with these traditionally-focussed modes, rather than rushing to assert the primacy of the human rights mode.

I have here advanced a very speculative point, but it does not strike me as one that is implausible. What does strike me is the way in which philosophical defences of human rights struggle to register this possibility. Thomas Pogge, unusually for the literature, is explicit about who he takes his audience to be: his argument only addresses 'affluent people everywhere... not because I see the poor as passive subjects rather than agents, but because I don't take myself to have any standing to advise them.'43 I can see why Pogge says so: due to the systemic injustices in the global institutional order that shape the global distribution of wealth the well-off, regardless of political or cultural context, have benefitted from neglect of human rights. Yet it is nonetheless remarkable that Pogge defines his audience solely in terms of an economic category. When political and cultural contexts are left out, there is no way of accounting for the sorts of complexities that exist in post-colonial contexts. And when those complexities are obscured, it is hard

\footnotetext{
${ }^{41}$ See further Quashigah, "Justice in the Traditional African Society Within the Modern Constitutional Set-Up".
}

42 On this point see Ajume Wingo, "The Odyssey of Human Rights”, Transition 102:1, 2010, 120-138.

43 Thomas Pogge, "Responses to the Critics", in A. Jaggar (ed.) Thomas Pogge and His Critics (Cambridge MA, Polity, 2010), 209. 
to see what underpins Pogge's confidence in the political effectiveness of the human rights mode of legitimation.

Most other global justice theorists are far less explicit about who they take their audiences to be. My impression is that most take themselves to be addressing the inhabitants of the world at large under the conditions of modernity. Yet that domain is frequently idealised, with participants in the practices of liberal modernity assumed to accept something of its liberalism. To give one example from a cornerstone of the literature, Jim Griffin defends a consensus on human rights by invoking the 'massive increase in global communication, convergence on economic structures, homogenization of ways of life due to growing prosperity, and widespread travel and study abroad precisely by the persons most likely to be influential in their societies'. ${ }^{44}$ This sort of idealised view is an unavoidable consequence of the justificatory strategy of appealing to the existence of a common substantive moral consensus. But it makes contemporary philosophical conceptions ill-equipped to account for the many ways in which the institutions of liberal capitalism are not so central to varied local forms of life that alternative constellations of ethical concepts are untenable.

The injustices in the global order that defenders of human rights highlight should put pressure on the assumption that reasonable modern individuals see these injustices in light of a concern with basic human rights. I would be very interested to know the extent to which the perception of these injustices, in post-colonial contexts of political activity, is inextricably bound up with the local history of colonisation, and with attempts at overcoming the continued effects and legacy of that history. It would not surprise me at all if, among bearers of local forms of life shaped by colonial impositions on culture, territory, and livelihood, the contemporary impacts of the unjust global order were viewed as continuations of the history of colonisation, to be cast within indigenous modes of legitimation. To the extent that this is the case, human rights talk is likely to represent, as it does for the Māori, an inappropriate mode of legitimation. That we struggle to register this possibility within philosophical justifications for human rights

\footnotetext{
44 Griffin, On Human Rights, 138. I should note that in Griffin's case, this appeal to agreement is one strand of a more complex justificatory cable: Griffin also offers a sophisticated argument about the intelligibility of certain basic values.
} 
invoking an assumed common consensus on moral value should also put pressure on the wisdom of such a justificatory strategy.

* For helpful comments I am grateful to Martin Ajei, Rowan Cruft, Katrin Flikschuh, Adrian Haddock, Eghosa Osaghae, Avia Pasternak, Kofi Quashigah, Andrew Sharp, Ajume Wingo, and audiences at the ALSP, the LSE, and the University of Ghana. 